\title{
METHODS OF TESTING AND ASSESSING THE TECHNICAL CONDITION OF CHOSEN BUILDING STRUCTURES LOCATED IN THE AREA OF THE AUSCHWITZ-BIRKENAU NATIONAL MUSEUM IN OŚWIĘCIM
}

\author{
Stanisław KAŃKA ${ }^{1}$, Teresa STRYSZEWSKA ${ }^{2}$, Tomasz TRACZ ${ }^{3}$ \\ Cracow University of Technology, Faculty of Civil Engineering, Kraków, Poland \\ Stanisław KARCZMARCZYK ${ }^{4}$, Roman PARUCH ${ }^{5}$ \\ Cracow University of Technology, Faculty of Achitecture, Kraków, Poland
}

\begin{abstract}
The results presented in this article consider the means of assessing the technical condition of two selected buildings, i.e. prisoner barracks number 123 and 124, located at the Auschwitz-Birkenau State Museum in Oświęcim. The work was carried out within the framework of a research project involving the development of methods for preserving, securing and strengthening the structure of buildings, along with their substrate and finishes. The aim of the project was to gain a knowledge base reflecting the actual state of the existing facilities and, on that basis, develop preservation methods and ways to protect the existing facilities against further damage, while maintaining the current character.
\end{abstract}

Keywords: technical condition, prisoner barracks, Auschwitz-Birkenau Concentration Camp

\footnotetext{
1 Corresponding author: Cracow University of Technology, Faculty of Civil Engineering, Warszawska st 24, 31-155 Kraków, Poland, e-mailskanka@pk.edu.pl, tel.+48126282389

2 tstryszewska@pk.edu.pl, tel.+48126282345

3 ttracz@pk.edu.pl, tel.+48126282387

${ }^{4}$ Cracow University of Technology, Faculty of Achitecture, Warszawska st 24, 31-155 Kraków, Poland, skarczmarczyk1@ poczta.onet.pl, tel.+48126282353

5 rparuch@pk.edu.pl, tel.+48126282353
} 


\section{INTRODUCTION}

In the year 2009, the realization of a multi-year comprehensive conservation program was commenced, aimed at maintaining the existing infrastructure as a memorial. The scope of this program included a research project encompassing the development of methods for preserving, protecting and strengthening the construction of buildings and the ground substrate of buildings located in the area of the Auschwitz-Birkenau National Museum in Oświęcim on the BI stretch.

The scope of the research project covered, among others:

- a geotechnical assessment of the terrain,

- inventory of deformations of the building structure and damage resulting from corrosion,

- macroscopic description (full photographic documentation),

- analysis of the physical and strength properties of materials built into the building structures, as well as tests using a wood resistograph,

- determining the degree of salinity of mineral materials in the masonry walls,

- static-strength calculations of construction elements.

The main aim of the works carried out was preparing an information base for each building, which will be used to prepare:

- conservation and renovation programs, and protection of elements of the finishing,

- projects of strengthening and securing the load-bearing structure and elements of furnishing,

- a project for protection against moisture and removing water and moisture from the buildings.

The accepted method of assessing the technical condition of buildings located in the area of the National Museum of Auschwitz-Birkenau in Oświęcim was presented on the basis of two prison barracks. Fig. 1 presents one of the analyzed prison barracks.

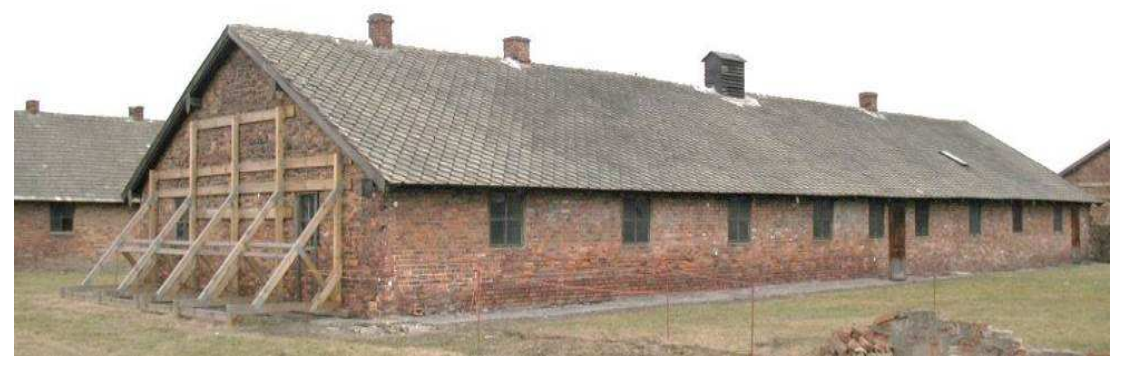

Fig 1. Prison barrack No. B-123 


\section{METHODOLOGY}

Analyses of mineral materials were carried out on core samples taken from masonry walls and foundations of the analyzed buildings in the form of boreholes 25 to $100 \mathrm{~mm}$ in diameter, determining the following: moisture content, density and compressive strength of the masonry wall, brick, mortar and concrete. Chemical analyses allowing for the content of salts affecting the durability of the analyzed materials to be determined were also carried out. Moreover, the load-bearing capacity of wooden rafters for selected elements removed from the construction of the roof was also determined (Fig. 3).

\subsection{Testing moisture content}

The determination of the moisture content of the ceramic brick and masonry wall was carried out using the drying and weighing method. The moisture content of wooden rafters was assessed using an electric pin-type moisture meter.

\subsection{Testing density}

Volume density was determined on samples which were regular in shape, in the case of ceramic brick - in a dry state, whereas for concrete - in a state of natural moisture content. Based on the measurement of mass and volume, the density of the analyzed materials was indicated.

\subsection{Testing strength}

Fig. 2 shows the methods of testing the compressive strength of materials taken from the structure accepted on the basis of literature [2].

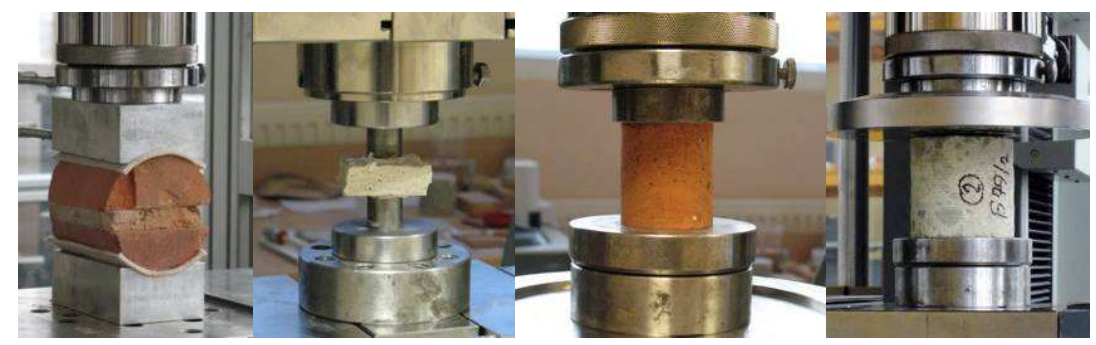

Fig. 2. Testing the compressive strength of the masonry wall, mortar, brick and concrete (from left)

\subsection{Testing salt content}

The content of sulfuric, chloride and nitrogen salts, influencing the durability of the analyzed materials, was carried out using the spectrophotometric method. 
The tests were carried out using extracts, which were additionally used to determine $\mathrm{pH}$ of the tested materials. WTA guidelines were used as the criterion of the level of salinity of the materials [4].

\subsection{Testing the load-bearing capacity of wooden rafters}

The analysis was carried out at a testing station equipped with an ISTS testing system (Fig. 4). The rafters were placed in a horizontal position by supporting them in the same areas as in the roof structure. Vertical force was applied by a traverse for a two-point bending scheme. The load stress was realized until a bend of L/150, i.e. $26.7 \mathrm{~mm}$ was reached, at a speed of $1 \mathrm{~mm} / \mathrm{min}$.

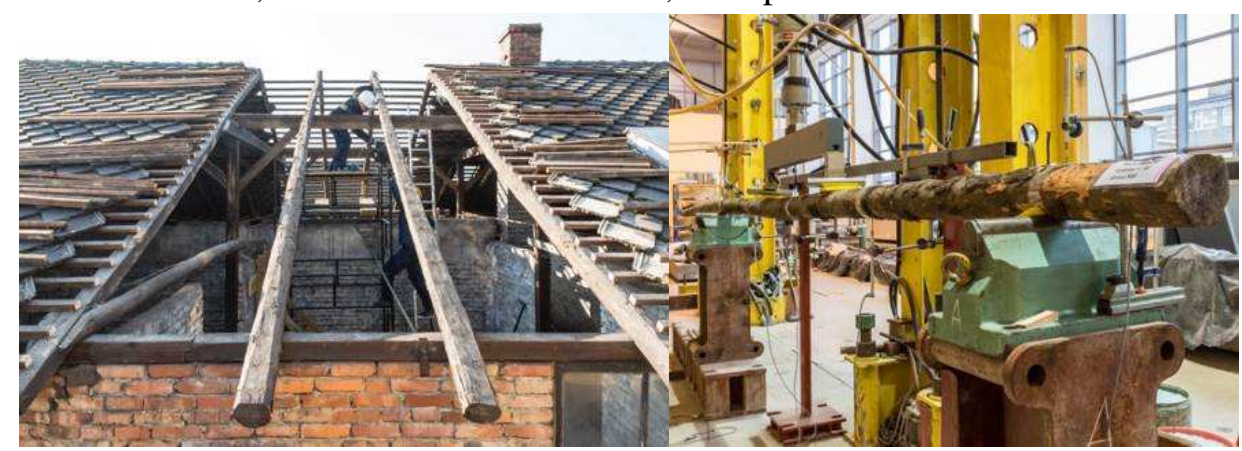

Fig. 3. Removal of rafters - barrack B-123

Fig. 4. Element at the testing station

The deviation of the analyzed rafters was registered at five measurement points using induction sensors. Two sensors were placed in the area of support, whereas the remaining three were installed under the rafter, spaced every $100 \mathrm{~cm}$ in the part between the supports. A series of measurements using a resistograph were also taken on the analyzed rafters.

Measurements of the diameter of the rafters were determined for fourteen points distributed along the entire length, every $50 \mathrm{~cm}$.

\section{RESULTS AND ANALYSIS}

Sample photographs of borehole samples taken from the building structures, their location, and results of conducted studies have been presented in Tab.1. The areas for collecting samples were chosen in such a way that enables the analysis of selected properties of materials in the wall height function.

Tab. 2, on the other hand, contains sample photographs of the analyzed elements, a view of the cross-section, as well as the results of studies and measurements carried out on the wooden rafters. Based on the obtained results, it can be stated that the material in the analyzed buildings is characterized by an acceptable moisture level - not exceeding 3\% [1]. The low level of moisture 
content was directly connected with the summer period during which the samples were collected. In the studies, variation in the moisture level was observed depending on where the collected sample was situated. On the whole, samples from the lower parts of the walls, near the ground, were characterized by the highest moisture content. An exception to this were samples taken from the upper parts of the wall, which underwent periodical dampening due to the roof getting wet. The low moisture content can be explained by the not very thick walls (approx. $12 \mathrm{~cm}$ ). Walls characterized by such thickness, despite periodical dampening during periods of increased humidity, dry quickly.

The studies revealed that the level of salinity of ceramic bricks, regardless of the type of salt, was generally low. A dependency on the level of salinity on the height at which the samples were taken from was not observed. It is worth noting that the low content of salt is an additional factor which facilitates the drying of walls [3]. On the other hand, noticeably higher concentrations of chloride and sulfuric salts and were registered in the mortars. According to WTA requirements [4], the level of mortar salinity was determined as medium. The $\mathrm{pH}$ of the analyzed mortars was similar to that of ceramic bricks, and ranged from 7.9 - 8.7. The low $\mathrm{pH}$ was connected with, among others, the progressing carbonization process of the lime binder, as well as the leaching and dissolution of its components. Testing the level of the salinity of concrete used in the foundations revealed a low level for all salts. The $\mathrm{pH}$ fell in the range of $10.8-12.0$, which is a sufficient value in the case of not reinforced concretes. A value of $\mathrm{pH}$ above 9 confirms that the basic component of cement binder has been preserved.

The material assessment of the masonry walls covered determining the proportion of binding substance to aggregate in mortars. The ratio fell in the range of $1 / 2.2-1 / 3.1$. The strength of mortar ranged from 5.2 to $11.1 \mathrm{MPa}$.

In assessing wall strength, the strength of ceramic brick, mortar and the wall fragment were all taken into account. The obtained values of wall strength differed significantly, ranging from 2.9 - 12.2 MPa. Attention ought to be drawn to the fact that strength was determined on the basis of samples taken from areas which were preserved in a state that made it possible to make boreholes. Thus, when assessing the load-bearing capacity, one ought to keep in mind that the analyzed buildings contain fragments of wall characterized by a lower strength than that mentioned above. 
Table 1. Results of tests on mineral materials

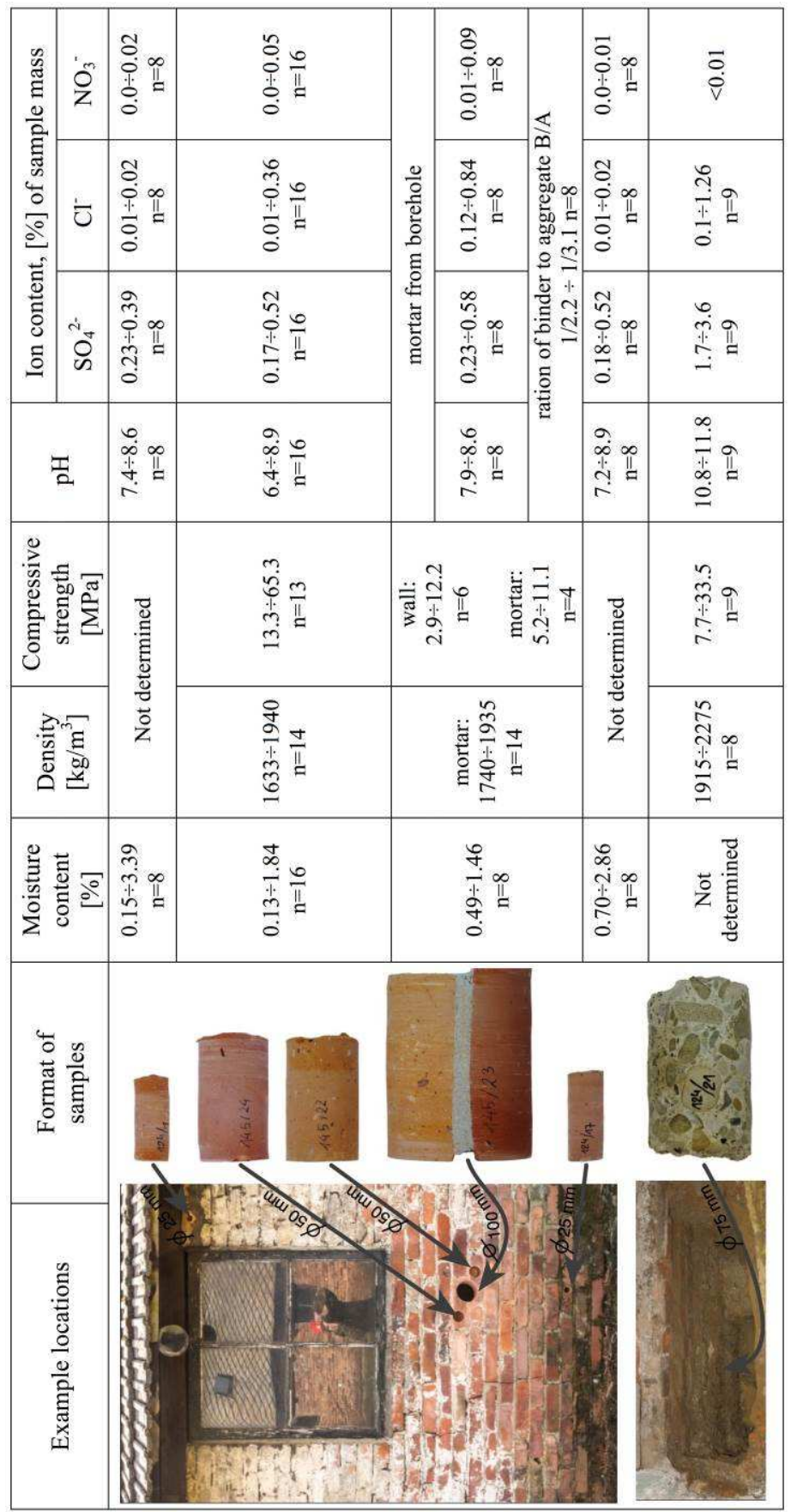


METHODS OF TESTING AND ASSESSING THE TECHNICAL CONDITION OF CHOSEN 47 BUILDING STRUCTURES LOCATED IN THE AREA OF THE AUSCHWITZ-BIRKENAU NATIONAL MUSEUM IN OŚWIĘCIM

Table 2. Scheme of applying load to rafters and compilation of results of cross-section measurements and load-bearing capacity tests
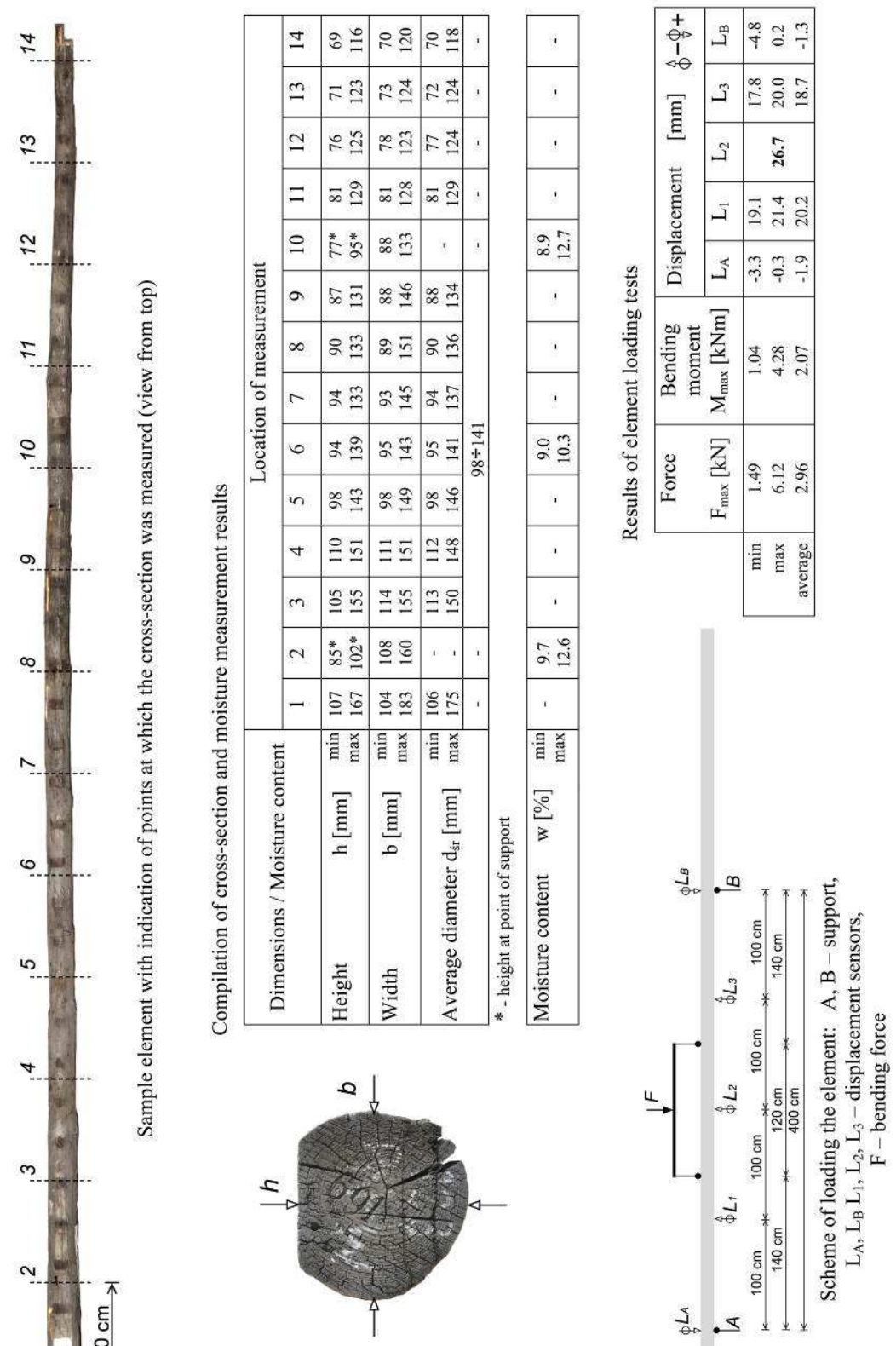
The analyzed rafters are characterized by highly varied measurements of the horizontal cross-section (reduced to the diameter), within the range of 98 to 141 $\mathrm{mm}$ along the length of the element. The moisture content of near surface layers of wood fluctuates between 8.9 and 12.7\%. A wide spread of results was registered during the course of tests on load-bearing capacity, where each beam was subjected to such a force of load that resulted in a $26.7 \mathrm{~mm}(\mathrm{~L} / 150)$ bend at the halfway point of the span. The values of these forces vary, falling within the range of 1.49 to $6.12 \mathrm{kN}$. The carried out static-strength analyses of the entire building, accounting for the results of laboratory studies, made it possible to present comprehensive methods for securing and strengthening the entire loadbearing structure of the prisoner barrack. The results of laboratory studies and calculation analysis indicated the need to take immediate action aimed at ensuring the safety of using the barrack for purposes of the museum and maintaining the doctrine of conservation.

\section{CONCLUSIONS}

The studies carried out on the building, identification of strength, physical and chemical properties of materials, as well as calculation analysis created the basis for assessing the technical condition connected with the safety level of the building. The condition for making buildings available to visitors is ensuring a level of safety determined according to guidelines set forth by the recommended and binding European norms. The main aim of the conducted studies was to prepare the foundation for developing the basis for preparing a project for securing and protecting the building under full preservation maintenance. In the case of buildings found in the area of the AuschwitzBirkenau State Museum, the main conservation and technical requirement is the need to maintain and enforce all original parts of the building and its furnishings as elements illustrating the living conditions that prisoners of the camp had to face.

\section{ADDITIONAL INFORMATION}

The study was carried out within the scope of the project: "Studies on developing conservation methods, securing and enforcing building constructions, elements of their finish as well as the ground substrate accounting for the statics and physics of buildings present in the area of the Auschwitz-Birkenau State Museum in Oświęcim," financed from the funds of the Auschwitz-Birkenau Foundation. 


\section{REFERENCES}

1. Adamowski J., Hoła J., Matkowski Z.: Problemy remontowe zawilgoconych monumentalnych obiektów barokowych, Renowacje i Zabytki, 1(13) (2005) 130-138.

2. Gruszczyński M., Matysek P.: Ocena wytrzymałości murów ceglanych na podstawie badań odwiertów rdzeniowych, Czasopismo Techniczne, 3-B (2011) 55-69.

3. Stryszewska T., Kańka S.: Microstructure of Ceramic Brick Contaminated by Magnesium Sulphate, Advances in Science and Technology, 92 (2014) 203-208.

4. WTA - Merkblatt 4-5-99/D Beurteilung von Mauerwerk Manerwerksdiagnostik.

\section{METODY BADANIA I OCENY STANU TECHNICZNEGO WYBRANYCH OBIEKTÓW KUBATUROWYCH ZNAJDUJACYCH SIE NA TERENIE PAŃSTWOWEGO MUZEUM AUSCHWITZ-BIRKENAU W OŚWIĘCIMIU}

\section{Streszczenie}

Przedstawione $\mathrm{w}$ artykule wyniki badań dotyczą metody oceny stanu technicznego wybranych dwóch obiektów kubaturowych tj. baraków więźniarskich o numerach B-123 i B-124, które znajdują się na terenie Państwowego Muzeum Auschwitz-Birkenau w Oświęcimiu. Prace były prowadzone w ramach projektu badawczego obejmującego opracowanie metod konserwacji, zabezpieczenia i wzmocnienia konstrukcji obiektów oraz ich podłoża i elementów wykończenia.

Celem projektu było pozyskanie bazy informacji odzwierciedlających rzeczywisty stan techniczny istniejących obiektów oraz opracowanie na ich podstawie metod konserwacji i sposobów zabezpieczenia przed dalszym degradacją pełnym zachowaniu cech odzwierciedlających charakter i pełnioną funkcję obiektu w obozie koncentracyjnym.

Słowa kluczowe: stan techniczny, barak więźniarski, Państwowe Muzeum Auschwitz-Birkenau

Editor received the manuscript: 06.02.2015 r. 
